Ramón Clares $\mathbf{P}$.

\title{
Poemas del fuego
}

\author{
I

\section{CREACIÓN}

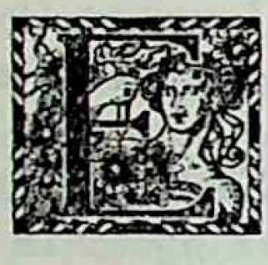

STA llama está oculta en su propio fulgor...

Hace los silencios

luminosos y hondos... Su presencia todo lo penetra y lo alumbra por dentro...

Esta llama disipa las palabras como gasas de niebla, y desnudo y ágil salta el pensamiento, como un hombre limpio de pecado en la quieta alegría del paisaje:

Arriba las estrellas se cuentan el milagro,

$y$ en sus ecos casi se escucha el verso que se cuajó en la voz del Dios-Poeta cuando miró en el rostro la Belleza...

Esta llama está oculta porque puede

mostrarlo todo y todas las pupilas pueden ver en su luz .. Todos los hombres son sus lámparas... Y en cada noche les va haciendo la carne más graciosa y más leve, hasta rompérsela 
en el costado, y formarles labios puros para alabar a Dios...

El blanco lienzo

se me llena de rosas encarnadas, cuando siento esta llama silenciosa como el amor, amándome...

\section{EXTASIS}

Para que me reconozcas, he quemado en la hoguera de las zarzas mis mantos y sandalias...

Estoy tan inmóvil en tu seno como lo está el Dolor, cuando el Olvido le aprieta el corazón entre sus manos... Mi cuerpo no da sombra, cuando entra mi camino en tu luz... Ningún hombre puede verme, porque sólo conocieron

mi sombra caminante...

En tu seno

mis pupilas se abrieron hacia adentro $y$ te miran llegar... Mis palabras no suenan en el aire, pero siento que me hablan en tu Voz... Cada cosa astro o flor, cuanto canta y cuanto ama. parécenme tan hondos que, como ecos, encuentro en todo el ritmo de tu nombre...

Para que me reconozcas, he quemado mis mantos y sandalias... y sé que estoy en $\mathrm{Ti}$, cuando los hombres sienten que sale un hombre de sus odios y que entra a sus dolores un hermano... 